$\mathbf{R}_{\text {ESE }}^{\text {RCH }}$ RTICLe

Members of the Research Forum Associate Author :

${ }^{1}$ Department of Veterinary and Animal Husbandry Extension Education, Veterinary College, Shivamogga (Karnataka) India

${ }^{2}$ Department of Veterinary and Public Health, Veterinary College, Shivamogga (Karnataka) India

${ }^{3}$ Department of Animal Nutrition, Veterinary College, Shivamogga (Karnataka) India

AUTHOR FOR CORRESPONDENCE : B.R. Manjith Kumar Department of Veterinary and Animal Husbandry Extension Education, Veterinary College, Shivamogga (Karnataka) India

Email :manjeetkumar2007@ gmail.com

\section{Socio-economic constrains and establishment of fodder nursery on production of dairy: a participatory approach in Jagalur taluk of Davanagere district}

K.C. Veeranna ${ }^{1}$, B.R. Manjith Kumar, C.B. Madavaprasad ${ }^{2}$ and V. Nagabhushan ${ }^{3}$

\begin{abstract}
The present study was conducted to assess the contribution of socio-economic characteristics of dairy farmers towards their entrepreneurial behaviour in Davanagere district of Karnataka. The data was collected using a semi structured and pre-tested interview schedule from 200 dairy farmers. The results revealed that majority of socio-economic characteristics like age, occupation, education, land holding etc. had significantly influenced their entrepreneurial behavior. It necessitates formulation and implementation of suitable education strategies to increase the level of entrepreneurial behaviour among the dairy farmers that in turn influences on productivity of milch animals. A live demonstration of fodder crops during 2017-18 was undertaken in Hoskere village of Jagalur taluk, Davanagere district, Karnataka, to educate the farmers in cultivating perennial fodder grasses. Interested farmer were selected randomly from the Hoskere village for demonstration of growing of fodder grass. The study revealed that the production of Napier grass such as CO-4 and CO-3 was 86 and 102 tons/ac/y, Guinea grass was 62 tons/ac/y, Rhodes grass was 73 tons/ac/y, Hedge Lucerne was 21 tons/ac/y, Grazing guinea was 77 tons/ac/y, Para grass was 52 tons/ac/y, Anjan grass was 58 tons/ac/y and Fodder sorghum was 31 tons/ac/y. The total annual expenditure per 2 gunta $\left(200 \mathrm{~m}^{2}\right)$ area of different fodder grass from fodder nursery plot was Rs. 11500 and if there is no maintenance of livestock in their farm the total income generated only from the nursery from different green fodder crops production was Rs. 25400. The net profit from different fodder crops from fodder nursery plot was Rs. 13900. Moreover, good quality and nutritional rich green fodder and dry fodder were available in the beneficiary farm from fodder trees and fodder crops all-round the year, Increased lactometer reading, Fat and SNF and milk production of the cross bred cows and finally earn the income around the year.
\end{abstract}

Key words : Constraints, Green fodder, Production, Profit, Socio-economic profile

How to cite this paper : Veeranna, K.C., Manjith Kumar, B.R., Madavaprasad, C.B. and Nagabhushan, V. (2018). Socio-economic constrains and establishment of fodder nursery on production of dairy: a participatory approach in Jagalur taluk of Davanagere district. Vet. Sci. Res. J., 9(1\&2) : 1-10, DOI : 10.15740/HAS/VSRJ/9.1and2/1-10. Copyright@2018: Hind Agri-Horticultural Society.

Paper History : Received : 16.08.2018; Revised : 11.09.2018; Accepted : 21.09.2018 